\title{
Article \\ Constrain on Oil Recovery Stage during Oil Shale Subcritical Water Extraction Process Based on Carbon Isotope Fractionation Character
}

\author{
Rongsheng Zhao ${ }^{1}\left(\mathbb{D}\right.$, Luquan Ren ${ }^{1}$, Sunhua Deng ${ }^{2}{ }^{\mathbb{D}}$, Youhong Sun ${ }^{3,4, *}$ and Zhiyong Chang ${ }^{1, *}$ \\ 1 Key Laboratory of Bionic Engineering, College of Biological and Agricultural Engineering, \\ Jilin University, Changchun 130021, China; 15246007162@163.com (R.Z.); lqren@jlu.edu.cn (L.R.) \\ 2 Key Laboratory of Drilling and Exploitation Technology in Complex Conditions, College of Construction \\ Engineering, Jilin University, Changchun 130021, China; denghua13@163.com \\ 3 School of Engineering and Techology, China University of Geosciences, Beijing 100080, China \\ 4 National-Local Joint Engineering Laboratory of In Situ Conversion, Drilling and Exploitation Technology for \\ Oil Shale, Jilin University, Changchun 130021, China \\ * Correspondence: syh@jlu.edu.cn (Y.S.); zychang@jlu.edu.cn (Z.C.)
}

Citation: Zhao, R.; Ren, L.; Deng, S.; Sun, Y.; Chang, Z. Constrain on Oil Recovery Stage during Oil Shale Subcritical Water Extraction Process Based on Carbon Isotope Fractionation Character. Energies 2021, 14, 7839. https://doi.org/10.3390/ en14237839

Academic Editor: Rouhi Farajzadeh

Received: 26 September 2021

Accepted: 4 November 2021

Published: 23 November 2021

Publisher's Note: MDPI stays neutral with regard to jurisdictional claims in published maps and institutional affiliations.

Copyright: (c) 2021 by the authors. Licensee MDPI, Basel, Switzerland. This article is an open access article distributed under the terms and conditions of the Creative Commons Attribution (CC BY) license (https:// creativecommons.org/licenses/by/ $4.0 /)$.

\begin{abstract}
In this work, Huadian oil shale was extracted by subcritical water at $365{ }^{\circ} \mathrm{C}$ with a time series $(2-100 \mathrm{~h})$ to better investigate the carbon isotope fractionation characteristics and how to use its fractionation characteristics to constrain the oil recovery stage during oil shale in situ exploitation. The results revealed that the maximum generation of oil is $70-100 \mathrm{~h}$, and the secondary cracking is limited. The carbon isotopes of the hydrocarbon gases show a normal sequence, with no "rollover" and "reversals" phenomena, and the existence of alkene gases and the $\mathrm{CH}_{4}-\mathrm{CO}_{2}-\mathrm{CO}$ diagram implied that neither chemical nor carbon isotopes achieve equilibrium in the $\mathrm{C}-\mathrm{H}-\mathrm{O}$ system. The carbon isotope $\left(C_{1}-C_{3}\right)$ fractionation before oil generation is mainly related to kinetics of organic matter decomposition, and the thermodynamic equilibrium process is limited; when entering the oil generation area, the effect of the carbon isotope thermodynamic equilibrium process $\left(\mathrm{CH}_{4}+2 \mathrm{H}_{2} \mathrm{O} \rightleftarrows \mathrm{CO}_{2}+4 \mathrm{H}_{2}\right)$ becomes more important than kinetics, and when it exceeds the maximum oil generation stage, the carbon isotope kinetics process becomes more important again. The $\delta^{13} \mathrm{C}_{\mathrm{CO}_{2}}-\mathrm{CH}_{4}$ is the result of the competition between kinetics and thermodynamic fractionation during the oil shale pyrolysis process. After oil begins to generate, $\delta^{13} \mathrm{C}_{\mathrm{CO}_{2}}-\mathrm{CH}_{4}$ goes from increasing to decreasing (first "turning"); in contrast, when exceeding the maximum oil generation area, it goes from decreasing to increasing (second "turning"). Thus, the second "turning" point can be used to indicate the maximum oil generation area, and it also can be used to help determine when to stop the heating process during oil shale exploitation and lower the production costs.
\end{abstract}

Keywords: oil shale; subcritical water; pyrolysis; gases; carbon isotope

\section{Introduction}

Oil shale has become an important backup energy of conventional fossil energy in the world, and its pyrolysis exploitation mode has changed from aboveground (ex situ) to underground (in situ) [1-8], as the former technology encounters significant challenges, such as environmental pollution and inefficiencies [2]. The in situ technology underground could be further divided into [3] (a) in situ artificial crushing and retorting and (b) real underground in situ retorting. Subcritical water extraction of oil shale is one of the in situ retorting technologies, and the oil generation process can be optimized through altering the heating time, type, and amount of catalyst and maximum temperature [4-9]. The quality of oil shale pyrolysis products mainly relates to the heating temperature and time [4], overheating or insufficient heating temperature will lead to a high mining cost with a low resource utilization rate; thus, precise heat transfer and adequate heating conditions are important to maximize oil yield [10]. In this sense, the early detection of 
the oil recovery stage during oil shale pyrolysis can lead to a quick corrective heating process being implemented, lowering the production costs. However, there are three main traditional methods for forecasting the oil shale pyrolysis process (organic matter decomposition): (1) direct measurement of vitrinite reflectance $\left(\% R_{\mathrm{o}}\right)$ [11], hydrocarbon generation $\left(\mathrm{T}_{\max }\right)$, and element ratios $(\mathrm{H}: \mathrm{C})$ of rock samples [12]; (2) indirect measurement through analyzing the structure and composition of rocks by wave-substance interaction using terahertz time-domain spectroscopy [13], Raman spectroscopy [14], and infrared spectroscopy et al. [15], or through analyzing the product and its isotope compositions according to empirical formula, using a mass spectrometer and isotope analyzer [16]; (3) numerical modeling method, which establishes kinetics data acquired from pyrolysis experiment (e.g., thermogravimetric analysis) or actual mining data $[17,18]$. These methods are either time consuming and expensive for the routine control of complicated sample preparations and analytical techniques, or it depends on an amount of experimental data that is hard to achieve in the early mining stage. Hence, a simple and quick method for indication of the oil shale pyrolysis process is still needed.

Carbon isotope geochemistry is one of the major tools for deciphering geologic processes that are both organic and inorganic [19]. It has been widely used to investigate the gas generation mechanism, organic matter formation environment, mixing process [20,21], and so on. Specially, with the maturity of carbon isotope detection technology, the $\delta^{13} \mathrm{C}$ of simple carbon-bearing molecules ( $\mathrm{CO}, \mathrm{CO}_{2}, \mathrm{CH}_{4}$, and light hydrocarbons) can be quickly recognized in the field, outside the laboratory, for example, for predicting natural gas recovery with shale gas exploitation [22] and the distribution of combustible ice [19]. A lot of research has been done on the effect of carbon isotope (mainly $\mathrm{CO}_{2}$ and $\mathrm{C}_{1}-\mathrm{C}_{3}$ ) characteristics on the oil shale pyrolysis process, and it can be used to determine the origin and migration pathways of natural gas [23], the thermal maturity stage of organic matter [24], natural gas types, and even to identify the prolific zones for gas recovery [25]. These applications are mainly based on an empirical equation established for actual field data and/or laboratory tests, and a good application effect has been achieved. Specifically, the "rollover" point (e.g., the $\delta^{13} \mathrm{C}_{\mathrm{C}_{2} \mathrm{H}_{6}}$ increasing with maturity and then decreasing) and "reversals" point (e.g., $\delta^{13} \mathrm{C}_{\mathrm{CH}_{4}}>\delta^{13} \mathrm{C}_{\mathrm{C}_{2} \mathrm{H}_{6}}>\delta^{13} \mathrm{C}_{\mathrm{C}_{3} \mathrm{H}_{8}}$ ) receive a lot of attention during oil shale pyrolysis process [20]. Nevertheless, those points are out of the maximum oil generation stage during the oil shale artificial mature process, in which the $\% R_{\mathrm{o}}$ is generally less than 1 [24]. Thus, this study is mainly focusing on filling this gap and indicating the oil generation area for the in situ exploitation of oil shale based on carbon isotope fractionation character research at the laboratory scale.

Carbon isotopes have a relatively slow exchange rate for many carbon-bearing minerals and are in relatively large fractionations even at high temperatures; those merits made it become an excellent recorder of geological processes [26,27]. Carbon isotope fractionation is a result of mass-dependent ${ }^{13} \mathrm{C} /{ }^{12} \mathrm{C}$-fractionation during the gas, fluid, or melts generation process [28]. The carbon isotope characteristics in those C-H-O systems are largely considered to be determined by kinetics or/and a thermodynamic equilibrium mechanism [29]. For the organic matter decomposition process, the carbon isotope of gases is mainly related to the former [30], and researchers have established many models to describe the carbon isotope evolution characteristics during natural gas generation process, e.g., the Rayleigh model [31], Cramer model [32], Tang model [33], etc. The effect caused by the thermodynamic equilibrium process has been rarely considered to date; there has been much debate in the literature about the relative importance of kinetics and thermodynamic equilibrium in controlling the isotopic distribution among $\mathrm{C}-\mathrm{H}-\mathrm{O}$ gases, especially in aqueous conditions [28,29]. The existence of $\mathrm{H}_{2} \mathrm{O}$ can promote the organic matter decomposition process and alter the gas composition [34], and then, the "frozen" carbon isotope characteristics determined by kinetics will be altered, especially for the carbon isotopes of $\mathrm{CH}_{4}$ and $\mathrm{CO}_{2}$ [34]. The carbon isotope thermodynamic equilibrium reversible process [29] introduced some limitations into the existing kinetics models when used. In addition, different organic matter composition will also have a great influence 
on the established kinetics modes [35]. Thus, it is important to explore new ways of using carbon isotopes. Additionally, a series of experiments have been conducted on the equilibrium partitioning of isotopic exchange reactions between $\mathrm{CO}_{2}$ and $\mathrm{CH}_{4}$ from 200 to $1200{ }^{\circ} \mathrm{C}[28,36]$, but to our knowledge, the only study on carbon isotope equilibrium characteristics in an organic matter decomposition process is without water [28], and in this condition, there is no obvious carbon isotope exchange between $\mathrm{CO}_{2}$ and $\mathrm{CH}_{4}$ without catalytic even at $400{ }^{\circ} \mathrm{C}$ with $614 \mathrm{~h}[28,29]$.

In this study, we heated an immature oil shale sample with a time series under controlled temperature and pressure in the presence of water at autoclaves. Our goals were as follows: (1) investigate the carbon isotope evolution characteristics below the max oil generation stage; (2) illuminate the possible mechanisms responsible for isotope fractionation; (3) evaluate if the carbon isotope fractionation characteristics based on kinetics and thermodynamic equilibrium can be used to indicate the oil generation characteristics during oil shale pyrolysis within water. This research can fill the gap in the literature on the indicators of the oil generation area, and it also could help optimize the heating process on future in situ oil shale exploitation.

\section{Material and Methods}

\subsection{Sample Preparation}

The oil shale used in this study was sampled from the fourth layer of the Dachengzi mine area, Huadian, Jilin Province, China, with $0.35 \% \mathrm{R}_{\mathrm{o}}$. Before being separated into $100 \mathrm{~g}$ samples for later experiments, the oil shale samples were crushed and sieved into a diameter around $0.60-0.90 \mathrm{~mm}$, and to reduce the experimental errors caused by sample heterogeneity, the samples were uniformly mixed [4]. To know the basic properties of HD oil shale, the proximate analysis, ultimate analysis, and Fischer assay analysis were conducted according to [6] (Table 1).

Table 1. Properties of HD oil shale samples.

\begin{tabular}{|c|c|c|c|c|c|}
\hline \multicolumn{2}{|c|}{ Proximate Analysis (wt \%, ad) } & \multicolumn{2}{|c|}{ Ultimate Analysis (wt \%, ad) } & \multicolumn{2}{|c|}{ Fischer Assay Analysis (wt \%) } \\
\hline Moisture & 3.36 & $\mathrm{C}$ & 40.40 & Shale oil & 16.08 \\
\hline Volatiles & 36.52 & $\mathrm{H}$ & 5.97 & Gas & 4.80 \\
\hline Fixed carbon & 3.42 & $\mathrm{~N}$ & 0.75 & Water & 5.77 \\
\hline Ash & 56.70 & S & 0.83 & Residue & 73.35 \\
\hline
\end{tabular}

\subsection{Pyrolysis Experiments}

First, the $100 \mathrm{~g}$ oil shale samples were put in $0.5 \mathrm{~L}$ stainless-steel autoclaves manufactured by Hai'an Oil Research Co., Ltd. of Jiangsu, China, with $200 \mathrm{~mL}$ of distilled water. Second, to remove the air in the top space of the autoclaves, high-pressure purity $\mathrm{N}_{2}(99.999 \%)$ was used at $4 \mathrm{MPa}$, and then, the $\mathrm{N}_{2}$ was released at ordinary pressure. This process was repeated three times. Third, the autoclaves were heated to $365^{\circ} \mathrm{C}$ by $1.5 \mathrm{~h}$; when they reached the set temperature, they were kept for 2, 4, 6, 8, 10, 20, 30, 50, 70 and $100 \mathrm{~h}$. The temperatures of the autoclaves were monitored by thermocouples, and the standard deviation was around $\pm 0.1{ }^{\circ} \mathrm{C}$. During the heating, the pressure was monitored by piezometers. The pressure was approximately $25 \mathrm{MPa}$ during all experiments at $365^{\circ} \mathrm{C}$, and this pressure was almost provided by the vapor pressure of water. At the end of each experiment, the autoclave was cooled down to room temperature at ice water; then, the gas and oil products were subsequently collected for further analyses (Figure 1). Additionally, here, we use oil recovery per unit rock sample mass (ORR) to represent the oil recovery stage during the oil shale pyrolysis process, which is equal to the ratio of oil product weight collected in the autoclaves to the oil shale sample weight. This term is not equivalent to the oil gas recovery factor in oil gas geology, which is the ratio of final oil production from a reservoir to petroleum geological reserves. 


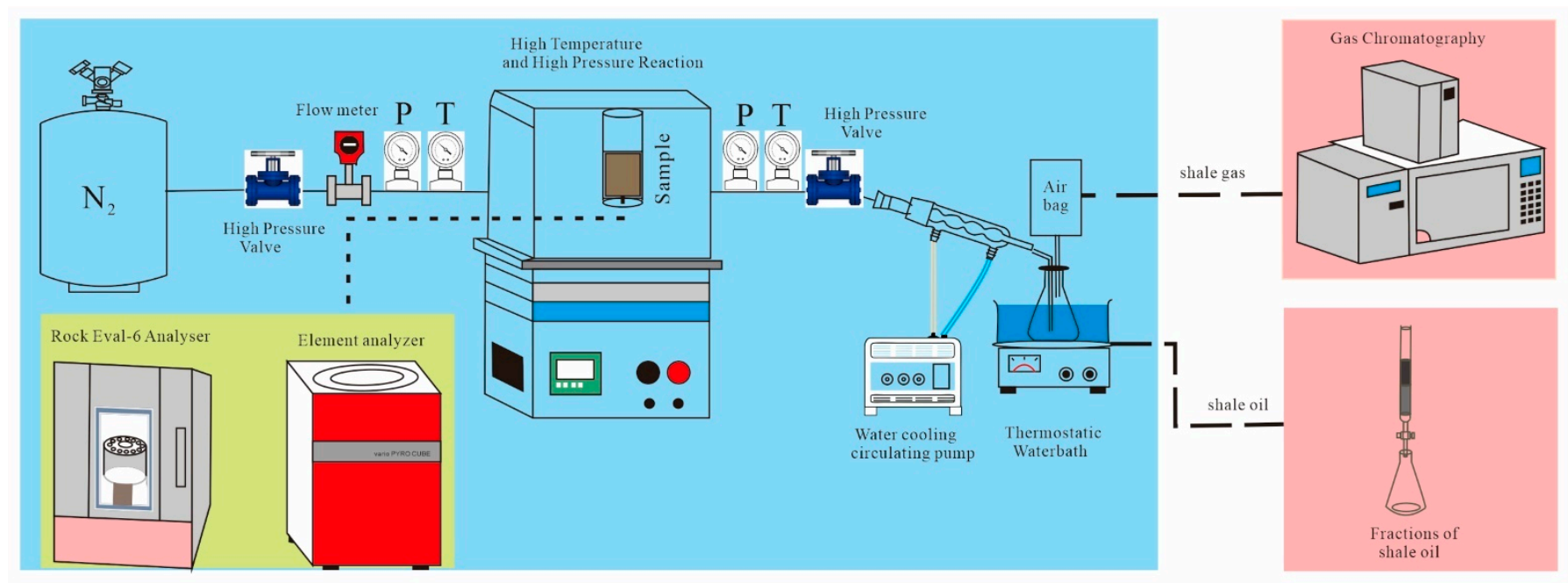

Figure 1. The experiments used in this study.

\subsection{Gas Compositional and Isotopic Analysis}

The gas products were collected at 2, 4, 6, 8, 10,20,30, 50, 70, and $100 \mathrm{~h}$ and analyzed by an Agilent 7890B gas chromatograph (GC) manufactured by Agilent, California, USA, with one injection at Jilin University. The GC was equipped with two thermal conductivity detectors (TCD) and a flame ionization detector (FID). $\mathrm{C}_{1}-\mathrm{C}_{6}$ were detected by FID using HP-AL/S columns $(25 \mathrm{~m} \times 0.32 \mathrm{~mm} \times 8 \mu \mathrm{m})$. TCD1 was used to detect $\mathrm{CO}_{2}, \mathrm{O}_{2}, \mathrm{~N}_{2}$, and $\mathrm{CO}$ using HayeSep A 80-100 mesh columns, and TCD2 was used to detect $\mathrm{H}_{2}$ using Molsieve 5 A 60/80 Mesh columns. All detection processes used He as the carrier gas. The content of the gas component was quantified based on a calibration gas sample (item number: A0908685), which was manufactured by the Scott company. The software used in calculation was Agilent OpenLab manufactured by Agilent, California, USA. A stable carbon isotope of gas $\left(\mathrm{CO}_{2}\right.$ and $\left.\mathrm{C}_{1}-\mathrm{C}_{3}\right)$ products is selectively tested at 2, 6, 10, 20, 30, 50, 70 , and $100 \mathrm{~h}$. The analysis was performed using Thermo Delta V Advantage isotope ratio mass spectrometry (IRMS) manufactured by Thermo Fisher Scientific, Waltham, USA, at the Daqing Petroleum Exploration and Development Research Institute, China. Carbon isotope ratios are reported in \% with respect to the VPDB standard. The precision in the measurements is $\pm 0.5 \%$ for $\delta^{13} \mathrm{C}$.

\section{Results and Discussion}

\subsection{Products Character}

The ORR has a faster increasing trend before $8 \mathrm{~h}$ from 0 to $11.36 \%$, and then, it is almost unchanged until $20 \mathrm{~h}$; between 20 and 70, it gradually increased (11.50-16.52\%) and then, it declined at $100 \mathrm{~h}(15.74 \%)$. The maximum value of ORR may be around $17 \%$ (Table 2 and Figure 2a), and this point corresponds to the secondary cracking speed of oil equal to its formation $[37,38]$. The evolution character of wetness $\left(\sum C_{2-5} / \Sigma C_{1-5}\right)$ after $8 \mathrm{~h}$ changed little with the experiment time (Figure $2 \mathrm{~b}$ ). The $\mathrm{CH}_{4}$ shows the largest yields among the $\mathrm{C}_{\mathrm{n}} \mathrm{H}_{\mathrm{m}}$ gases generated (Figure $2 \mathrm{c}$ ). The paths of $\mathrm{C}_{2} \mathrm{H}_{6}$ and $\mathrm{C}_{3} \mathrm{H}_{8}$ are similar to the continuously increasing yields of $\mathrm{CH}_{4}$ at all times; this character made it difficult for the alkane to indicate the ORR evolution characteristics during the oil shale exploitation process. Small amounts alkene gases are generated, and in contrast to $\mathrm{C}_{2} \mathrm{H}_{6}$, the $\mathrm{C}_{2} \mathrm{H}_{4}$ continued declining as the time increased (Table 2). The existence of unstable alkene gases indicated that the $\mathrm{C}-\mathrm{H}-\mathrm{O}$ gases have not achieved equilibrium in the system, and then, a second cracking process happened, which will lower the generated oil weight [39]. The plot of $\ln \left(C_{1} / C_{2}\right)$ versus $\ln \left(C_{2} / C_{3}\right)$ is useful for distinguishing the secondary cracking process [40] in which the secondary cracking of forming heavy hydrocarbon gases and oil will increase the $\ln \left(C_{2} / C_{3}\right)$ value and decrease the $\ln \left(C_{1} / C_{2}\right)$ value. If the decomposition rates exceed the generation rates, the $\ln \left(C_{2} / C_{3}\right)$ will increase sharply as $\ln \left(C_{1} / C_{2}\right)$ increases. 
The $\ln \left(C_{1} / C_{2}\right)$ value of pyrolysis gas varies from 0.29 to 0.67 , whereas the $\ln \left(C_{2} / C_{3}\right)$ value varies from 0.16 to 0.58 with a linear relationship in this study (Figure $2 \mathrm{~d}$ ), and the slope around 1 of Figure $2 \mathrm{~d}$ may imply that the decomposition and generation rate of oil is closed to balanced and the ORR has reached its maximum.

Table 2. The yields and stable carbon isotopic compositions of gaseous products.

\begin{tabular}{|c|c|c|c|c|c|c|c|c|c|c|c|c|c|c|}
\hline Time & $\mathrm{C}_{1} \mathrm{H}_{4}$ & $\mathrm{C}_{2} \mathrm{H}_{6}$ & $\mathrm{C}_{2} \mathrm{H}_{4}$ & $\mathrm{C}_{3} \mathrm{H}_{8}$ & $\mathrm{C}_{3} \mathrm{H}_{6}$ & $\mathrm{CO}_{2}$ & $\mathrm{CO}$ & $\mathbf{H}_{2}$ & Wetness Index ${ }^{a}$ & $\mathrm{ORR}^{\mathrm{b}}$ & $\mathrm{CH}_{4}$ & $\mathrm{C}_{2} \mathrm{H}_{6}$ & $\mathrm{C}_{3} \mathrm{H}_{8}$ & $\mathrm{CO}_{2}$ \\
\hline h & \multicolumn{9}{|c|}{ Volume (\%) } & Weight (\%) & \multicolumn{4}{|c|}{$\delta^{13} C(\%$, VPDB $)$} \\
\hline 2 & 3.84 & 0.87 & 0.18 & 0.28 & 0.12 & 54.95 & 1.03 & 3.90 & 28.36 & 6.13 & -36.8 & -31.96 & -29.79 & -8.19 \\
\hline 4 & 4.89 & 1.74 & 0.19 & 0.77 & 0.28 & 63.18 & 0.53 & 4.73 & 42.20 & 7.18 & - & - & - & - \\
\hline 6 & 5.78 & 1.98 & 0.18 & 0.78 & 0.25 & 64.38 & 0.45 & 3.49 & 38.05 & 9.02 & -36.96 & -29.58 & -27.94 & -5.95 \\
\hline 8 & 6.08 & 2.19 & 0.17 & 0.96 & 0.29 & 62.84 & 0.30 & 5.84 & 41.26 & 11.36 & - & - & - & - \\
\hline 10 & 6.74 & 2.45 & 0.17 & 1.08 & 0.30 & 64.11 & 0.29 & 6.23 & 41.14 & 11.39 & -37.54 & -29.68 & -27.11 & -5.69 \\
\hline 20 & 8.30 & 3.14 & 0.14 & 1.42 & 0.34 & 64.02 & 0.24 & 7.81 & 41.67 & 11.50 & -39.55 & -30.69 & -29.39 & -7.11 \\
\hline 30 & 10.88 & 3.95 & 0.09 & 1.81 & 0.32 & 61.93 & 0.11 & 8.14 & 39.52 & 15.31 & -38.79 & -30.16 & -28.89 & -6.65 \\
\hline 50 & 12.4 & 4.60 & 0.09 & 2.25 & 0.38 & 56.8 & 0.14 & 9.27 & 40.95 & 15.73 & -38.59 & -29.85 & -28.49 & -6.83 \\
\hline 70 & 13.45 & 5.12 & 0.06 & 2.66 & 0.34 & 61.94 & 0.05 & 6.46 & 41.95 & 16.52 & -38.55 & -30.8 & -29.11 & -7.56 \\
\hline 100 & 14.69 & 5.54 & 0.05 & 2.85 & 0.30 & 59.25 & 0.03 & 6.16 & 41.03 & 15.74 & -38.95 & -30.98 & -29.37 & -7.54 \\
\hline
\end{tabular}

Note: “-" means no detection; “a” is calculated by $\sum \mathrm{C}_{2-5} / \sum \mathrm{C}_{1-5}$; “b” is calculated by the oil product weight/oil shale sample weight. In addition, since the $\mathrm{C}_{4+}$ gas components are not shown, their total volume is not equal to $100 \%$.
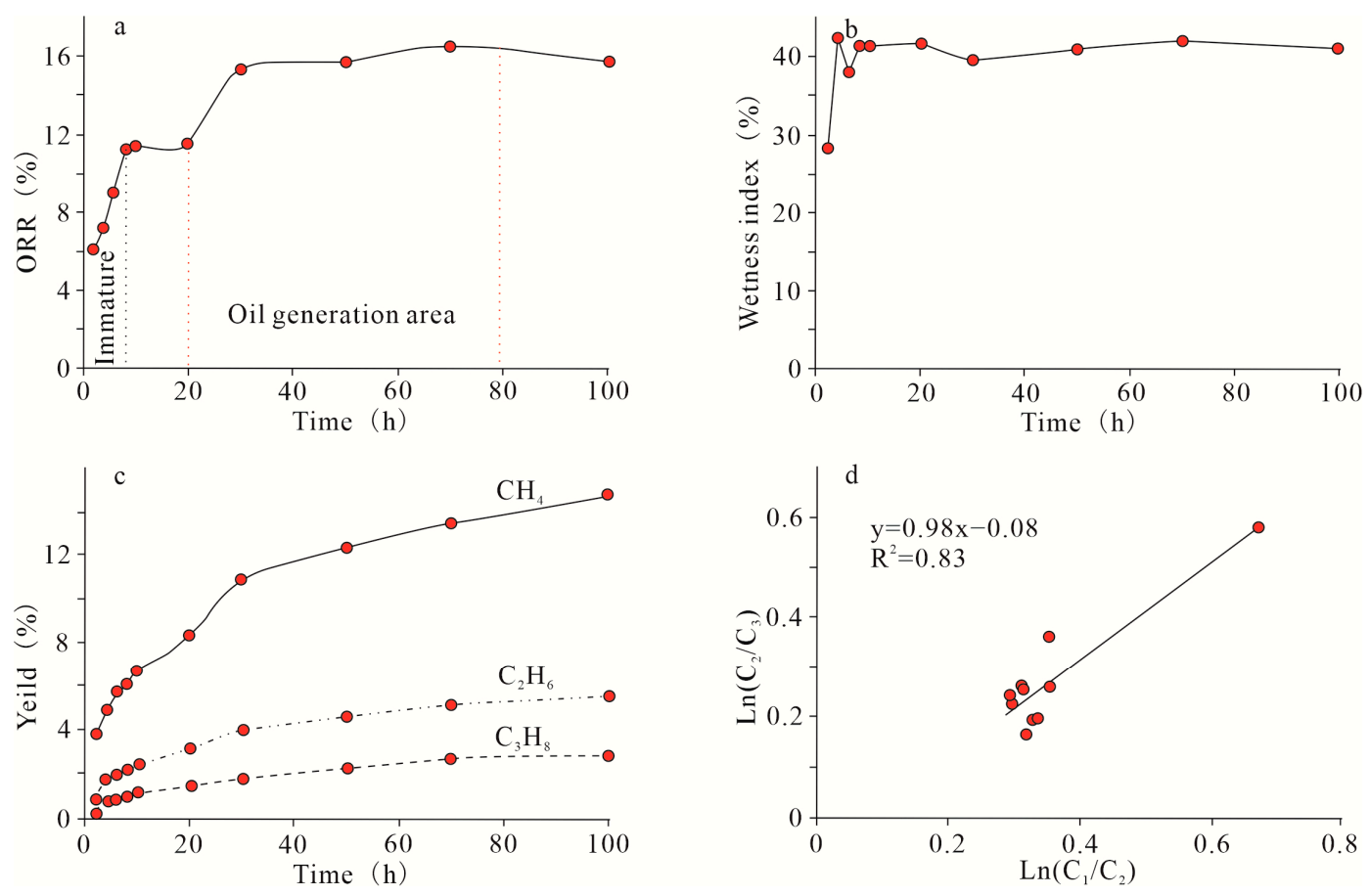

Figure 2. The evolution characteristics of ORR (a) wetness (b) and organic gases (c) during the pyrolysis of oil shale with time series; (d) the plots of $\ln \left(\mathrm{C}_{1} / \mathrm{C}_{2}\right)$ versus $\ln \left(\mathrm{C}_{2} / \mathrm{C}_{3}\right)$ for gas products.

There are also considerable amounts $\mathrm{CO}_{2}$ and $\mathrm{H}_{2}$ generated, but the formation of $\mathrm{CO}$ is limited, and its formation rate continues declining as the time increases (Figure $3 \mathrm{a}$ ). The formation of $\mathrm{CO}_{2}$ can occur from the breaking of $\mathrm{C}-\mathrm{O}, \mathrm{C}=\mathrm{O}$ bonds during organic matter thermal decay and the decomposition of carbonate minerals [41], and the hydration and/or oxidation process $\left(\mathrm{CH}_{4} \rightarrow \mathrm{CO} \rightarrow \mathrm{CO}_{2}\right)$ can also form it [29,35]. The reaction process is shown below: 


$$
\begin{gathered}
\mathrm{CH}_{4}+2 \mathrm{H}_{2} \mathrm{O} \rightleftarrows \mathrm{CO}_{2}+4 \mathrm{H}_{2} \\
\mathrm{CH}_{4}+3 \mathrm{CO}_{2} \rightleftarrows 4 \mathrm{CO}+2 \mathrm{H}_{2} \mathrm{O} \\
2 \mathrm{CO} \rightleftarrows \mathrm{C}+\mathrm{CO}_{2}
\end{gathered}
$$
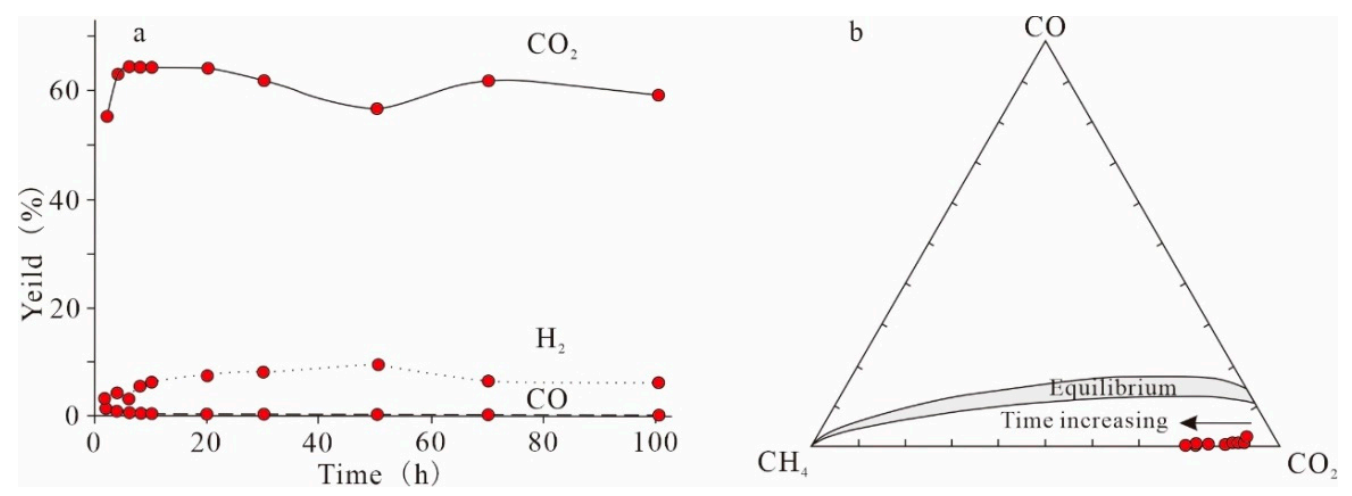

Figure 3. The evolution character of inorganic gases (a) during pyrolysis of oil shale with time series; $(\mathbf{b}) \mathrm{CH}_{4}-\mathrm{CO}_{2}-\mathrm{CO}$ diagram (modified from [21]); the gray field represents the thermodynamic equilibrium of $\mathrm{CH}_{4}-\mathrm{CO}_{2}-\mathrm{CO}$ gases.

The obviously high concentration of $\mathrm{H}_{2}$ and $\mathrm{CO}$ at all experiment times implied the existence of hydration (1) and oxidation reactions (2)-(3) throughout. Those reactions may be the main processes for $\mathrm{CO}_{2}$ generation, as it has a very high content (54.95-64.3\%; Table 2), and this character has been verified by comparison experiments between the oil shale pyrolysis process with water and without water [42]. Additionally, the $\mathrm{CO}$ is an intermediate product, and its decreasing formation rate over time implied that the $\mathrm{C}-\mathrm{H}-\mathrm{O}$ system is developing toward equilibrium. This evolution character can be seen in the $\mathrm{CH}_{4}-\mathrm{CO}_{2}-\mathrm{CO}$ diagram (Figure $3 \mathrm{~b}$ ), and this conclusion is also similar to the analysis of $\mathrm{C}_{\mathrm{n}} \mathrm{H}_{\mathrm{m}}$ gases outlined before.

Before discussion of the carbon isotope fraction characteristics, it is necessary to know the gas species formation mechanism, as the carbon isotope will be "frozen" after the gas is generated; thus, the carbon isotope fractionation is limited during collisions between molecules of gases [29]. There are three possible pathways for organic-inorganic reactions during hydrous pyrolysis [43,44]: (1) free radical mechanisms, where free radicals generated by the homolysis of organic matters were captured by water or water-derived hydrogen [34]; (2) ionic mechanisms, consisting of the reaction between water-derived $\mathrm{H}^{+}$and alkenes and alkanes [28,37]; (3) oxidation or hydration mechanisms, which the direct reaction of alkenes by $\mathrm{CO}_{2}$ or water [35]. Those reaction mechanisms can all occur in the hydrous pyrolysis, but the former may relate to the kinetic fraction of the carbon isotope, while the other two are related to thermodynamic equilibrium [23,35]. According to the quantum chemistry calculation, the ionic mechanism is more significant during high-temperature water-hydrocarbon reactions, while the free radial mechanism may play a more important role in geological conditions with temperature lower than $250{ }^{\circ} \mathrm{C}$, but their effect on the carbon isotope fractionation result is the same [35]. Even though the oxidation or hydration mechanism has a low reaction rate, as it has to overcome higher energy barriers, the phenomenon in which the amounts of $\mathrm{CO}_{2}, \mathrm{CO}$, and $\mathrm{H}_{2}$ generated in the presence of water are always significantly higher than without water indicated that the presence of $\mathrm{H}_{2} \mathrm{O}$ can foster the oxidation and/or hydration process [42]. Thus, as the isotope fractionation result is similar between the free radial and ionic reaction mechanisms as gases formed through organic matter decomposition [23], the final carbon isotope character in the C-H-O system may be decided by the degree of oxidation and/or hydration process through Reactions (1)-(3) at the end of the time period. 


\subsection{Carbon Isotopes Character}

Carbon isotopes produced during the thermal cracking of organic matter are useful for assigning the degree of gas recovery with water presence [45]. This is mainly based on the detection of the carbon isotope "rollover point" $\left(1.5 \% \mathrm{R}_{\mathrm{o}}\right)$, which correlates well with the highest production of hydrocarbon gases [23], or the "reversal point", which needs an even higher maturity with a $\% \mathrm{R}_{\mathrm{o}}$ always higher than 2.0 [46]. However, those points are all beyond the highest oil generation area and were not discovered in our low time $(0-100 \mathrm{~h})$ oil shale subcritical water recovery process (Figure 4). The time-series carbon isotope evolution of methane, ethane, and propane shows a similar isotope trend $\delta^{13} C_{1}<\delta^{13} C_{2}<\delta^{13} C_{3}$. The $\delta^{13} \mathrm{C}$ ranges for $\mathrm{CH}_{4}, \mathrm{C}_{2} \mathrm{H}_{6}$, and $\mathrm{C}_{3} \mathrm{H}_{8}$ were $-39.55 \%$ to $-36.80 \%$, $-31.96 \%$ o to $-29.58 \%$, and $-29.79 \%$ to $-27.11 \%$, respectively (Table 2 ). The hydrocarbon gas shows the origin of organic matter, while the $\delta^{13} \mathrm{C}_{\mathrm{CO}_{2}}$ is much higher than without the water pyrolysis experiment and moving toward an inorganic carbon isotope. Its increasing characteristics may be related to the continuous isotope exchange between the gas product and carbonates in the rock $[34,35]$.

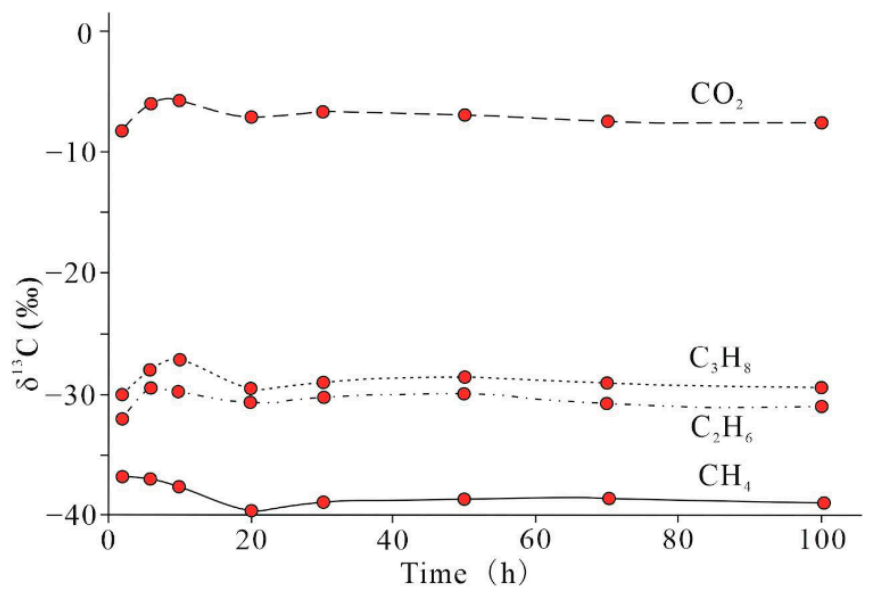

Figure 4. Stable carbon isotope values for $\mathrm{CO}_{2}, \mathrm{CH}_{4}, \mathrm{C}_{2} \mathrm{H}_{6}$, and $\mathrm{C}_{3} \mathrm{H}_{8}$ with increasing times at $365^{\circ} \mathrm{C}$.

The attainment of chemical equilibrium is a prerequisite for the attainment of isotopic equilibrium because isotopic exchange is most likely driven by the same elementary chemical reactions among $\mathrm{C}-\mathrm{H}-\mathrm{O}$ gases [29]. The existence of the alkene gases and $\mathrm{CH}_{4}-\mathrm{CO}_{2}-\mathrm{CO}$ diagram all implied that the chemical has not achieved equilibrium; this character also

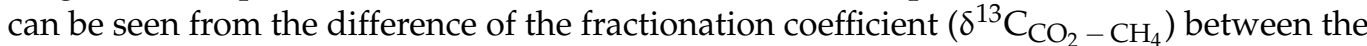
actual measurement and equilibrium condition at $365^{\circ} \mathrm{C}$ (Figure 5a). The $\delta^{13} \mathrm{C}_{2}-\delta^{13} \mathrm{C}_{3}$ versus $\ln \left(C_{2} / C_{3}\right)$ shows the gases that emerged mainly from primary cracking before $70 \mathrm{~h}$ (Figure $5 b$ ) featured larger ratios of ethane to propane and smaller carbon isotopic differences between ethane and propane with the differences below $-3 \%$ [47]. This implied that the carbon isotope fraction of $\mathrm{CH}_{4}$ was only slightly influenced by the secondary cracking of $C_{2}$ and $C_{3}$ to $C_{1}$. However, while the continuous primary cracking process will lead to the $\delta^{13} \mathrm{C}_{\mathrm{CH}_{4}}$ increasing with time, the newly formed $\mathrm{CH}_{4}$ will have a low $\delta^{13} \mathrm{C}$ value based on secondary cracking, as the ${ }^{12} \mathrm{C}$ will enter gases more than ${ }^{13} \mathrm{C}$ [45]. thus, the decreasing of $\delta^{13} \mathrm{C}_{\mathrm{CH}_{4}}$ after $70 \mathrm{~h}$ is mainly related to the mixing process between primary and secondary cracking. As studied by others, the isotope exchange between $\mathrm{CO}_{2}$ and $\mathrm{CH}_{4}$ below $500{ }^{\circ} \mathrm{C}$ at $614 \mathrm{~h}$ cannot be seen [29] at a low temperature, and it only takes place with a catalyst, e.g., $\mathrm{Ni}[28]$. 

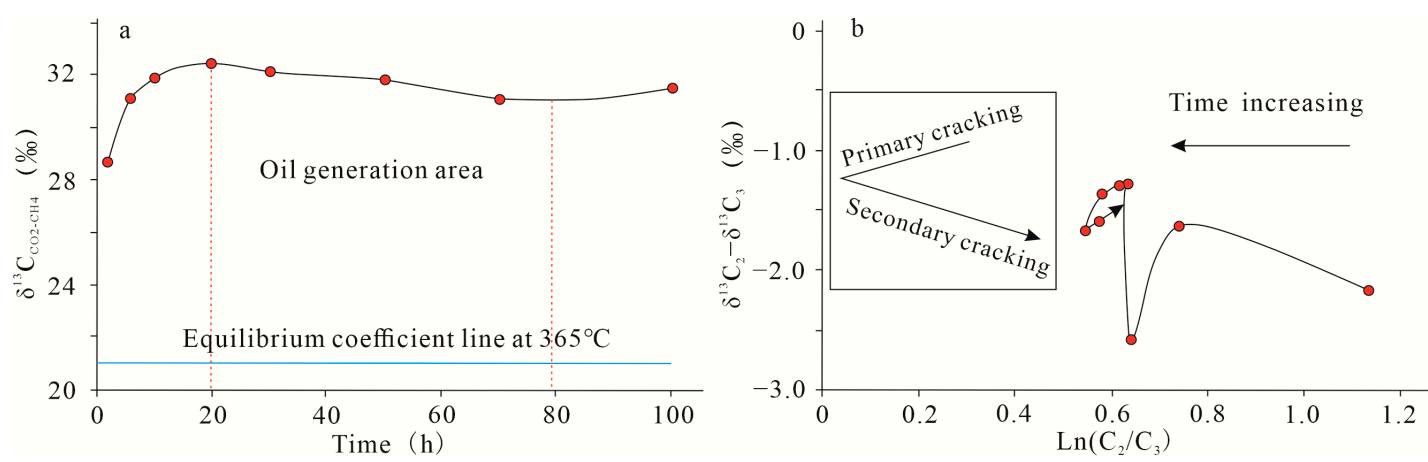

Figure 5. Carbon isotope fractionation coefficient between $\mathrm{CO}_{2}$ and $\mathrm{CH}_{4}(\mathbf{a})$ and plots of $\ln \left(\mathrm{C}_{2} / \mathrm{C}_{3}\right)$ versus $\delta^{13} \mathrm{C}_{2}-\delta^{13} \mathrm{C}_{3}$ (b) from time-series pyrolysis experiments. The calculated equilibrium coefficient at $365{ }^{\circ} \mathrm{C}$ was based on the study [29]; “ $b$ ” is modified from [47].

In general, the carbon isotopes of gases formed through the kinetics process will continue increasing, as ${ }^{12} \mathrm{C}$ will enter gases first [48]. However, the evolution of the carbon isotopes took on a wavy shape, especially in the initial stage of pyrolysis (before $20 \mathrm{~h}$; see Figure 4). This phenomenon has been observed in numerous studies, which state that it is mainly caused by the heterogeneity of the carbon isotopic composition of the organic structures. For example, $[20,33]$ assumed that the initial trend of decreasing $\delta^{13} \mathrm{C}$ values is due to mixing with the methane that is generated from lighter isotopic and heavy methyl groups. As mentioned before, the oxidation and/or hydration process is throughout our time-series experiments. Thus, the carbon isotope fraction formed by kinetics has been altered by thermodynamic fractionation to varying degrees. The speed of the thermodynamic fractionation process is mainly controlled by the chemical reaction rate, which is mainly influenced by the gas concentration, temperature, and pressure $[29,35]$. In our experiment, the temperature is constant, and the pressure has little changes. Therefore, the thermodynamic fractionation speed is mainly controlled by the gas concentration, especially the concentration of $\mathrm{CH}_{4}$. This process, in contrast to kinetics, will make the $\delta^{13} \mathrm{C}_{\mathrm{CO}_{2}-\mathrm{CH}_{4}}$ decrease until reaching equilibrium. Hence, the $\delta^{13} \mathrm{C}_{\mathrm{CO}_{2}-\mathrm{CH}_{4}}$ is the composition results from the kinetics and thermodynamic fractionation. To check the real $\mathrm{CH}_{4}$ generation characteristics, we recovered it based on chemical Reactions (1)-(3). During calculation, the $\mathrm{CO}_{2}$ was regarded as formed all from Reaction (1), as the release of $\mathrm{CO}_{2}$ from organic matter decomposition during the immature stage is limited. The recovered result can be seen in Table 3, in which the concentration of $\mathrm{CH}_{4}$ increased with time, leading the carbon isotope altered by thermodynamic fractionation to also increase. However, the generated rate of $\mathrm{CH}_{4}$ is not constant (Figure 6a), and this change is reflected in the changing $\delta^{13} \mathrm{C}_{\mathrm{CO}_{2}}-\mathrm{CH}_{4}$ values as time increases (Figure 5a): it has a great increase before $20 \mathrm{~h}$, and after this point, the change decreases before increasing again $(70-100 \mathrm{~h})$. This change feature is similar to the evolution of ORR (Figure 2a).
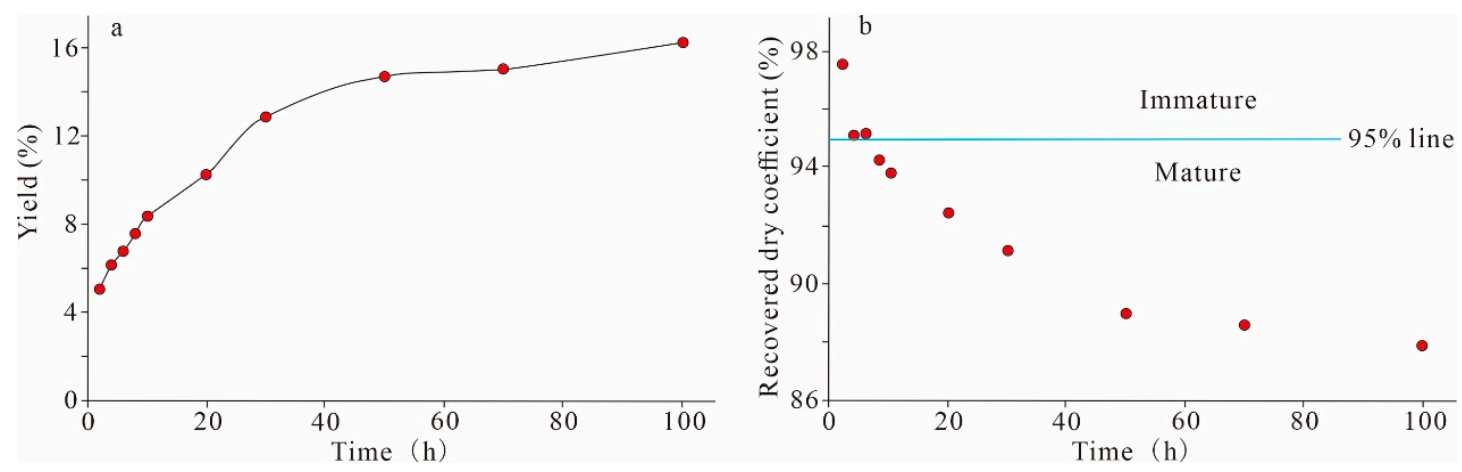

Figure 6. Recovered $\mathrm{CH}_{4}(\mathbf{a})$ and dry coefficient (b) evolution characteristics with time increasing. 
Table 3. The recovered gas characteristics based on Reactions (1)-(3) at $365^{\circ} \mathrm{C}$.

\begin{tabular}{cclc}
\hline Time & $\mathbf{C}_{\mathbf{1}} \mathbf{H}_{\mathbf{4}}$ & $\mathbf{C O}_{\mathbf{2}}$ & Recovered Dry Coefficient $^{\mathbf{a}}$ \\
\hline $\mathbf{h}$ & \multicolumn{3}{c}{ Volume (\%) } \\
\hline 2 & 5.07 & 55.72 & 97.52 \\
4 & 6.21 & 63.58 & 95.05 \\
6 & 6.77 & 64.72 & 95.21 \\
8 & 7.62 & 63.07 & 94.19 \\
10 & 8.37 & 64.33 & 93.79 \\
20 & 10.31 & 64.20 & 92.44 \\
30 & 12.94 & 62.01 & 91.12 \\
50 & 14.75 & 56.91 & 88.97 \\
70 & 15.08 & 61.98 & 88.58 \\
100 & 16.24 & 59.27 & 87.86 \\
\hline
\end{tabular}

Note: "aa" is calculated by $\mathrm{C}_{1} / \sum \mathrm{C}_{1-5}$.

\subsection{The Indicative Significance of the Carbon Isotope to ORR}

As the $\delta^{13} \mathrm{C}_{\mathrm{CO} 2-\mathrm{CH} 4}$ shows phase change characteristics, we further checked the $\delta^{13} \mathrm{C}_{\mathrm{CO}_{2}-\mathrm{CH}_{4}}$ vs. ORR relation. Figure $7 \mathrm{a}$ shows three obvious stages within the experiment time. Before $20 \mathrm{~h}$, the $\delta^{13} \mathrm{C}_{\mathrm{CO}_{2}}-\mathrm{CH}_{4}$ increases faster with the ORR (stage 1); then, it decreased until the ORR reaches its maximum at $70 \mathrm{~h}$ (stage 2). In the ORR reduction area, the $\delta^{13} \mathrm{C}_{\mathrm{CO}_{2}-\mathrm{CH}_{4}}$ increases again (stage 3). According to the pyrolysis products characteristics, stage 1 corresponds to the gas generation stage with a faster generation rate (Figure 6a), but the ORR increases fast before $8 \mathrm{~h}$ and then changes little between 8 and $20 \mathrm{~h}$ (Figure 2a). Stage 2 is the main oil generation stage; the ORR shows an obvious increase, but the increased $\mathrm{CH}_{4}$ generation rate slows down (Figure 6a). Stage 3 is related to the rapid oil cracking stage, in which the $\mathrm{C}_{2} / \mathrm{C}_{3}$ decreases rapidly (Figure $7 \mathrm{~b}$ ) and the $\mathrm{CH}_{4}$ generated rate quickly increases again (Figure 6a). Additionally, there is a large variation of pyrolysis products before $8 \mathrm{~h}$, and after this point, the variation of ORR is little; this area may be matching the immature stage of organic matter. As shown in the calculation results (Table 3; Figure $6 \mathrm{~b}$ ), the dry coefficient is higher than $95 \%$ before $8 \mathrm{~h}$; according to the empirical results, the dry coefficient higher than $95 \%$ is related to immature stage of organic matter, and under $95 \%$, the organic matter enters the mature stage [49]. Thus, the large variation of pyrolysis products during the immature stage may be contributed to its retained oil and gas before with little newly formed oil [50].
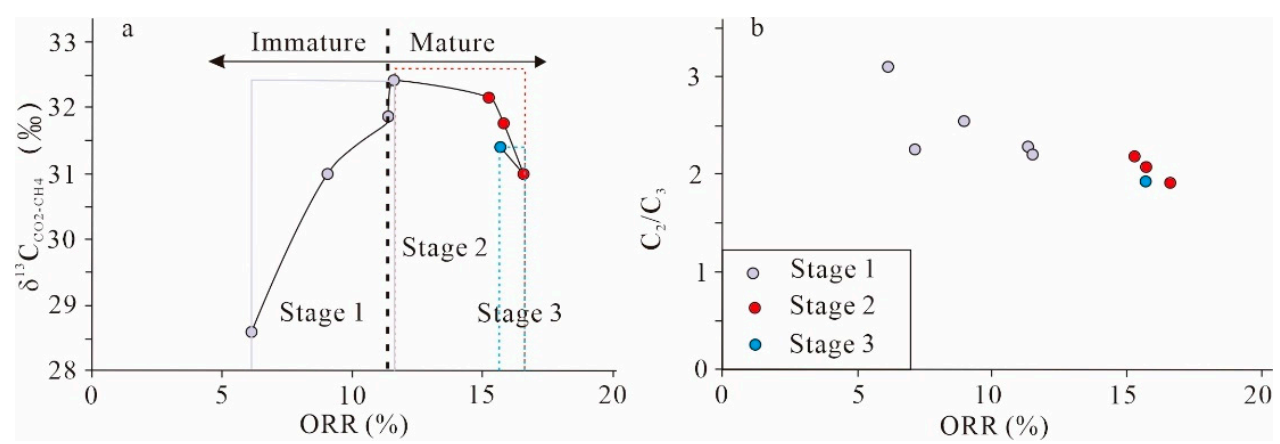

Figure 7. Evolution characteristics of $\delta^{13} \mathrm{C}_{\mathrm{CO}_{2}}-\mathrm{CH}_{4}$ with ORR at time series (a) and plot of $\mathrm{C}_{2} / \mathrm{C}_{3}$ with ORR (b).

In stage 1 , the increase in the $\delta^{13} \mathrm{C}_{\mathrm{CO}_{2}}-\mathrm{CH}_{4}$, before $8 \mathrm{~h}$, is perhaps related to the diffusion process with the continued desorption of the retained gas, as the $\mathrm{CO}_{2}$ is heavier than $\mathrm{CH}_{4}$, and the ${ }^{12} \mathrm{C}$ has spill precedence [48]. In addition, due to the existence of $\mathrm{H}_{2}$, $\mathrm{CO}_{2}$, and $\mathrm{CO}$, we think it is also influenced by the varying degrees of thermodynamic fractionation. When the organic matter matures $(8-20 \mathrm{~h}$; Figure 6a) in stage 1, the organic matter begins to decompose with the lowest $\delta^{13} \mathrm{C}_{\mathrm{CH}_{4}}$ value (Figure 4), which causes the $\delta^{13} \mathrm{C}_{\mathrm{CO}_{2}-\mathrm{CH}_{4}}$ value to suddenly go up, and almost no oil is formed (Figure $\left.7 \mathrm{a}\right)$. In this 
area $(8-20 \mathrm{~h})$, the influence of the kinetics fraction is stronger than the thermodynamic fractionation; thus, the $\delta^{13} \mathrm{C}_{\mathrm{CO}_{2}-\mathrm{CH}_{4}}$ also increases faster than before. When entering stage 2, compared to stage 1, the ORR increased slowly over time (20-70 h, Figure 2a); on the contrary, the $\delta^{13} \mathrm{C}_{\mathrm{CO}_{2}-\mathrm{CH}_{4}}$ decreases, and there is the first "turning" of $\delta^{13} \mathrm{C}_{\mathrm{CO}_{2}-\mathrm{CH}_{4}}$ from increasing to decreasing (Figure 7a). Even though it still shows a kerogen cracking character with limited oil and gas cracking (Figure $5 b$ ), the $\delta^{13} \mathrm{C}_{\mathrm{CO}_{2}-\mathrm{CH}_{4}}$ decreased with time, which means that the thermodynamic fractionation becomes more important than the kinetic fraction, which is mainly controlled by hydration (Reaction (1)) and the oxidation

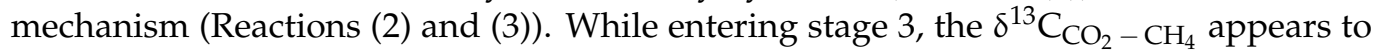
have a second "turning" from decreasing to increasing again, as the oil is cracking faster than its generation, which indicated that the kinetic fractionation plays a dominant role again (Figure $7 \mathrm{~b}$ ). Thus, the first $\delta^{13} \mathrm{C}_{\mathrm{CO}_{2}-\mathrm{CH}_{4}}$ "turning" point indicates that new oil begins to form, and the ORR increased with time, while once the second "turning" point appears, the ORR has reached its maximum and is about to start to decline.

Specially, in this study, we did not consider the effect of pressure, temperature, and rock characteristics on the carbon isotope fraction process. According to other research, the pressure has a suppression effect of gas generation in the early stage from 20 to $90 \mathrm{MPa}$, with a maximum carbon isotope fractionation effect of $\approx 3 \%$, and it increases with temperature from 350 to $373{ }^{\circ} \mathrm{C}$ [51]. However, the effect on the $\delta^{13} \mathrm{C}_{\mathrm{CO}_{2}}-\mathrm{CH}_{4}$ characteristics may be less, as it is a relative change. The organic matter type with a heterogenous structure in the rock may also have an influence on the carbon isotope fractionation, but the evolution characteristic of $\delta^{13} \mathrm{C}_{\mathrm{CO}_{2}-\mathrm{CH}_{4}}$ may be slight, as the gas product at different decomposition stages is similar to that of different organic matter [30]. Thus, the result of this research can be used to indicate the oil shale pyrolysis process, and it can help determine when to stop heating during oil shale exploitation and lower the production costs.

\section{Conclusions}

The carbon isotope fractionation characteristics and its constraints on the oil recovery stage during oil shale in situ exploitation are studied based on the subcritical water extraction process of Huadian oil shale at $365^{\circ} \mathrm{C}$. The results revealed the following: (1) the carbon isotope of hydrocarbon gas shows a normal sequence, before ORR decreasing, the secondary crack process has little effect on the carbon isotope composition, which is mainly controlled by the kinetics during the gas formation; (2) after the decomposition process, the formed carbon isotopes are altered by the thermodynamic equilibrium process based on the oxidation and/or hydration mechanism; (3) the two "turning" points of $\delta^{13} \mathrm{C}_{\mathrm{CO}_{2}}-\mathrm{CH}_{4}$ ' which is controlled by the competition between the kinetics and thermodynamic fractionation process, can be constrained at the oil generation stage. Specially, the influence of organic matter type, heterogeneity, temperature, pressure, and catalyst on the $\delta^{13} \mathrm{C}_{\mathrm{CO}_{2}}-\mathrm{CH}_{4}$ evolution characteristics needs further research before using. During the in situ pyrolysis process, the mixing and migration process will also have an influence on the carbon isotope fractionation in some way.

Author Contributions: Conceptualization, R.Z., Y.S., L.R. and Z.C.; methodology, R.Z. and S.D.; software, S.D.; validation, R.Z.; formal analysis, R.Z.; investigation, R.Z.; resources, Z.C. and S.D; data curation, R.Z. and S.D.; writing-original draft preparation, R.Z.; writing-review and editing, R.Z.; visualization, R.Z.; supervision, R.Z.; project administration, Z.C.; funding acquisition, Z.C. and R.Z. All authors have read and agreed to the published version of the manuscript.

Funding: This research was funded by National Natural Science Foundation of China, grant number 42002153; Department of Education, People's Government of Jilin Province, grant number JJKH20211111KJ; China Postdoctoral Science Foundation, grant number 2021M691193; National Natural Science Foundation of China, grant number 51875245; The Science-Technology Development Plan Project of Jilin Province, grant number 20190303012SF, 20190303003SF, 20190303118SF; The Special Project of Industrial Technology Research and Development of Jilin Province, grant number 2020C023-6; The "13th Five-Year Plan" Scientific Research Foundation of the Education Department 
of Jilin Province, grant number JJKH20201000KJ; and the Talent Development Foundation of Jilin Province, grant number 2020015.

Acknowledgments: We thank Shijie Kong for the help during experiment. And also thank for Xiaohui Wen for the help of sample preparation.

Conflicts of Interest: The authors declare no conflict of interest.

\section{References}

1. Jiang, X.; Han, X.; Cui, Z. New technology for the comprehensive utilization of Chinese oil shale resources. Energy 2007, 32, 772-777. [CrossRef]

2. Selberg, A.; Viik, M.; Pall, P.; Tenno, T. Environmental impact of closing of oil shale mines on river water quality in North-Eastern Estonia. Oil Shale 2009, 26, 169. [CrossRef]

3. Kang, Z.; Zhao, Y.; Yang, D. Review of oil shale in-situ conversion technology. Appl. Energ. 2020, 269, 115121. [CrossRef]

4. Sun, Y.; Kang, S.; Wang, S.; He, L.; Guo, W.; Li, Q.; Deng, S. Subcritical Water Extraction of Huadian Oil Shale at $300{ }^{\circ}$ C. Energy Fuels 2019, 33, 2106-2114. [CrossRef]

5. Jiang, X.; Cui, H.; Liu, M.; Guo, Q.; Xu, J.; Yang, J.; Yang, Y.; Li, Y.W. Extracting coal liquids from direct coal liquefaction residue using subcritical water. Energy Fuels 2016, 30, 4520-4528. [CrossRef]

6. Kang, S.; Sun, Y.; Qiao, M.; Li, S.; Deng, S.; Guo, W.; Li, J.; He, W. The enhancement on oil shale extraction of FeCl3 catalyst in subcritical water. Energy 2022, 238, 121763, in progress. [CrossRef]

7. Zendehboudi, S.; Bahadori, A. Shale Oil and Gas Handbook: Theory, Technologies, and Challenges; Gulf Professional Publishing: Houston, TX, USA, 2015.

8. Lu, H.; Jia, F.; Guo, C.; Pan, H.; Long, X.; Liu, G. Effect of shale ash-based catalyst on the pyrolysis of Fushun oil shale. Catalysts 2019, 9, 900. [CrossRef]

9. $\quad$ Bicker, M.; Endres, S.; Ott, L.; Vogel, H. Catalytical conversion of carbohydrates in subcritical water: A new chemical process for lactic acid production. J. Mol. Catal. A Chem. 2005, 239, 151-157. [CrossRef]

10. Jiang, H.; Hong, W.; Zhang, Y.; Deng, S.; Chen, J.; Yang, C.; Ding, H. Behavior, kinetic and product characteristics of the pyrolysis of oil shale catalyzed by cobalt-montmorillonite catalyst. Fuel 2020, 269, 117468. [CrossRef]

11. Spigolon, A.; Lewan, M.; Barros, P.; Coutinho, L.; Mendonça, F. Evaluation of the petroleum composition and quality with increasing thermal maturity as simulated by hydrous pyrolysis: A case study using a Brazilian source rock with Type I kerogen. Org. Geochem. 2015, 83-84, 27-53. [CrossRef]

12. Shao, D.; Zhang, T.; Kob, L.T.; Li, Y.; Yan, J.; Zhang, L.; Luo, H.; Qiao, B. Experimental investigation of oil generation, retention, and expulsion within Type II kerogen-dominated marine shales: Insights from gold-tube nonhydrous pyrolysis of Barnett and Woodford Shales using miniature core plugs. Int. J. Coal Geol. 2020, 217, 103337. [CrossRef]

13. Zhan, H.; Wang, Y.; Chen, M.; Chen, R.; Zhao, K.; Yue, W. An optical mechanism for detecting the whole pyrolysis process of oil shale. Energy 2019, 190, 116343. [CrossRef]

14. Kibria, M.; Das, S.; ·Hu, Q.; Basu, A.; Hu, W.; Mandal, S. Thermal maturity evaluation using Raman spectroscopy for oil shale samples of USA: Comparisons with vitrinite reflectance and pyrolysis methods. Petrol. Sci. 2020, 17, 567-581. [CrossRef]

15. Lis, G.P.; Mastalerz, M.; Schimmelman, A.; Lewan, M.; Stankiewicz, B. FTIR absorption indices for thermal maturity in comparison with vitrinite reflectance R0 in type-II kerogens from Devonian black shales. Org. Geochem. 2005, 36, 1533-1552. [CrossRef]

16. Prinzhofer, A.; Mello, M.; Silva, F.; Takaki, T. New geochemical characterization of natural gas and its use in oil and gas evaluation AAPG Memoir 2000, 73, 107-119.

17. Behar, F.; Lorant, F.; Lewan, M. Role of NSO compounds during primary cracking of a Type II kerogen and a Type III lignite. Org. Geochem. 2008, 39, 1-22. [CrossRef]

18. Lei, G.; Li, Z.; Yao, C.; Zheng, Y.; Wang, N.; Wang, Z. Numerical simulation on in-situ upgrading of oil shale via steam injection. J. China Univ. Petrol. 2017, 41, 100-107. (In Chinese)

19. Leonte, M.; Wang, B.; Socolofsky, S.A.; Mau, S.; Breier, J.A.; Kessler, J.D. Using Carbon Isotope Fractionation to Constrain the Extent of Methane Dissolution into the Water Column Surrounding a Natural Hydrocarbon Gas Seep in the Northern Gulf of Mexico. Geochem. Geophys. Geosystems 2018, 19, 4459-4475. [CrossRef]

20. Xia, X.; Chen, J.; Braun, R.; Tang, Y. Isotopic reversals with respect to maturity trends due to mixing of primary and secondary products in source rocks. Chem. Geol. 2012, 339, 205-212. [CrossRef]

21. Pan, C.; Yu, L.; Liu, J.; Fu, J. Chemical and carbon isotopic fractionations of gaseous hydrocar-bons during abiogenic oxidation. Earth Planet. Sci. Lett. 2006, 246, 70-89. [CrossRef]

22. Gao, L.; Wu, S.; Deev, A.; Olson, R.; Mosca, F.; Zhang, S.; Ni, Y.; Qu, Q.; LaFollette, R.; Chen, G.; et al. The gas isotope interpretation tool: A novel method to better predict production decline. AAPG Bull. 2017, 101, 1263-1275. [CrossRef]

23. Schoell, M. The hydrogen and carbon isotopic composition of methane from natural gases of various origins. Geochim. Cosmochim. Acta 1980, 44, 649-661. [CrossRef]

24. Gao, L.; Schimmelmann, A.; Tang, Y.; Mastalerz, M. Isotope rollover in shale gas observed in laboratory pyrolysis experiments: Insight to the role of water in thermogenesis of mature gas. Org. Geochem. 2014, 68, 95-106. [CrossRef] 
25. Zumberge, J.; Ferworn, K.; Brown, S. Isotopic reversal ('rollover') in shale gases produced from the Mississippian Barnett and Fayetteville formations. Mar. Pet. Geol. 2011, 31, 43-52. [CrossRef]

26. Bottinga, Y. Calculated fractionation factors for carbon and hydrogen isotope exchange in the system calcite-carbon dioxidegraphite-methane-hydrogen-water vapor. Geochim. Cosmochim. Acta 1969, 33, 49-64. [CrossRef]

27. Polyakov, V.; Kharlashina, N. The use of heat-capacity data to calculate carbon-isotope fractionation between graphite, diamond and carbon-dioxide-A new approach. Geochim. Cosmochim. Acta 1995, 59, 2561-2572. [CrossRef]

28. Kueter, N.; Schmidt, M.; Lilley, M.; Bernasconi, S. Experimental determination of equilibrium $\mathrm{CH}_{4}-\mathrm{CO}_{2}-\mathrm{CO}_{\text {carbon isotope }}$ fractionation factors $\left(300-1200^{\circ} \mathrm{C}\right)$. Earth Planet. Sci. Lett. 2019, 506, 64-75. [CrossRef]

29. Horita, J. Carbon isotope exchange in the system $\mathrm{CO}_{2}-\mathrm{CH}_{4}$ at elevated temperatures. Geochim. Cosmochim. Acta 2001, 65, 1907-1919. [CrossRef]

30. Lu, S.; Li, J.; Xue, H.; Chen, F.; Xu, Q.; Wang, M.; Li, W.; Pang, X. Pyrolytic Gaseous Hydrocarbon Generation and the Kinetics of Carbon Isotope Fractionation in Representative Model Compounds with Different Chemical Structures. Geochem. Geophys. Geosystems 2019, 20, 1773-1793. [CrossRef]

31. Berner, U.; Faber, E.; Stahl, W. Mathematical simulation of the carbon isotopic fractionation between huminitic coals and related methane. Chem. Geol. 1992, 94, 315-319. [CrossRef]

32. Cramer, B.; Faber, E.; Gerling, P.; Krooss, B. Reaction kinetics of Stable carbon isotopes in natural gass: Insights from dry, open system pyrolysis. Energy Fuel. 2001, 15, 517-532. [CrossRef]

33. Tang, Y.; Perry, J.; Jenden, P.; Schoell, M. Mathematical modeling of stable carbon isotope ratios in natural gases. Geochim. Cosmochim. Acta 2000, 64, 2673-2687. [CrossRef]

34. He, K.; Zhang, S.; Mi, J.; Zhang, W. Pyrolysis involving n-hexadecane, water and minerals: Insight into the mechanisms and isotope fractionation for water-hydrocarbon reaction. J. Anal. Appl. Pyrolysis 2018, 130, 198-208. [CrossRef]

35. He, K.; Zhang, S.; Mi, J.; Zhang, W. The evolution of chemical groups and isotopic fractionation at different maturation stages during lignite pyrolysis. Fuel 2017, 211, 492-506. [CrossRef]

36. Sackett, W. The thermal stability of methane from $600-1000{ }^{\circ} \mathrm{C}$. Org. Geochem. 1995, 23, 403-405. [CrossRef]

37. Li, Q.; Fu, X.; Li, J.; Wang, Y.; Lv, X.; Hu, C. Effect of heating rate on yields and distribution of oil products from the pyrolysis of pubescen. Energy Technol. 2018, 6, 366-378. [CrossRef]

38. Deng, S. Sub-critical water extraction of organic matter from oil shale lumps. J. Anal. Appl. Pyrolysis 2012, 98, 151-158. (In Chinese) [CrossRef]

39. Tian, H.; Xiao, X.; Wilkins, R.; Tang, Y. An experimental comparison of gas generation from three oil fractions: Implications for the chemical and stable carbon isotopic signatures of oil cracking gas. Org. Geochem. 2012, 46, 96-112. [CrossRef]

40. Prinzhofer, A.A.; Huc, A.Y. Genetic and post-genetic molecular and isotopic fractionations in natural gases. Chem. Geol. 1995, 126, 281-290. [CrossRef]

41. Wang, Q.; Xie, Z.; Jia, C.; Li, C. Characteristics of gases evolution during Huadian oil shale pyrolysis. Chem. Ind. Eng. Prog. 2017, 3, 4416-4422. (In Chinese)

42. Gao, J.; Liu, J.; Ni, Y. Gas generation and its isotope composition during coal pyrolysis: The catalytic effect of nickel and magnetite. Fuel 2018, 222, 74-82. [CrossRef]

43. Lewan, M.D.; Roy, S. Role of water in hydrocarbon generation from Type-I kerogen in Mahogany oil shale of the Green River Formation. Org. Geochem. 2011, 42, 31-41. [CrossRef]

44. Seewald, J.S. Organic-inorganic interactions in petroleum-producing sedimentary basins. Nature 2003, 426, 327-333. [CrossRef] [PubMed]

45. Liu, Q.; Wu, X.; Wang, X.; Jin, Z.; Zhu, D.; Meng, Q.; Huang, S.; Liu, J.; Fu, Q. Carbon and hydrogen isotopes of methane, ethane, and propane: A review of genetic identification of natural gas. Earth Sci. Rev. 2018, 190, 247-272. [CrossRef]

46. Wu, Y.; Zhang, Z.; Sun, L.; Li, Y.; Zhang, M.; Ji, L. Stable isotope reversal and evolution of gas during the hydrous pyrolysis of continental kerogen in source rocks under supercritical conditions. Int. J. Coal Geol. 2019, 205, 105-114. [CrossRef]

47. Li, W.; Zhu, Y.-M.; Liu, Y. Gas evolution and isotopic fractionations during pyrolysis on coals of different ranks. Int. J. Coal Geol. 2018, 188, 136-144. [CrossRef]

48. Duan, Y.; Sun, T.; Qian, Y.; He, J.; Zhang, X.; Xu, L.; Wu, B. Pyrolysis experiments of forest marsh peat samples with different maturities: An attempt to understand the isotopic fractionation of coalbed methane during staged accumulation. Fuel 2012, 94, 480-485. [CrossRef]

49. Lu, S.; Zhang, M. Petroleum Geochemistry; Petroleum Industry Press: Beijing, China, 2008. (In Chinese)

50. Hou, L.; Ma, W.; Luo, X.; Liu, J. Characteristics and quantitative models for hydrocarbon generationretention-production of shale under ICP conditions: Example from the Chang 7 member in the Ordos Basin. Fuel 2020, 279, 118497. [CrossRef]

51. Xie, L.; Sun, Y.; Uguna, C.N.; Li, Y.; Snape, C.E.; Meredith, W. Thermal cracking of oil under water pressure up to 900 bar at high thermal maturities: 1. Gas compositions and carbon isotopes. Energy Fuel 2016, 30, 2617-2627. [CrossRef] 